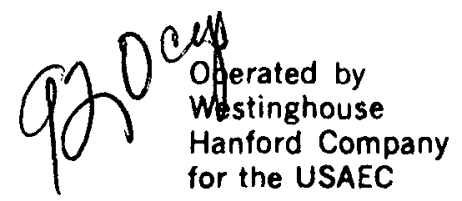

A subsidiary of

Westinghouse Electric

Corporation

\title{
RDT Standards
}

Transmittal

\section{Manford Engineering Development Laboratory}

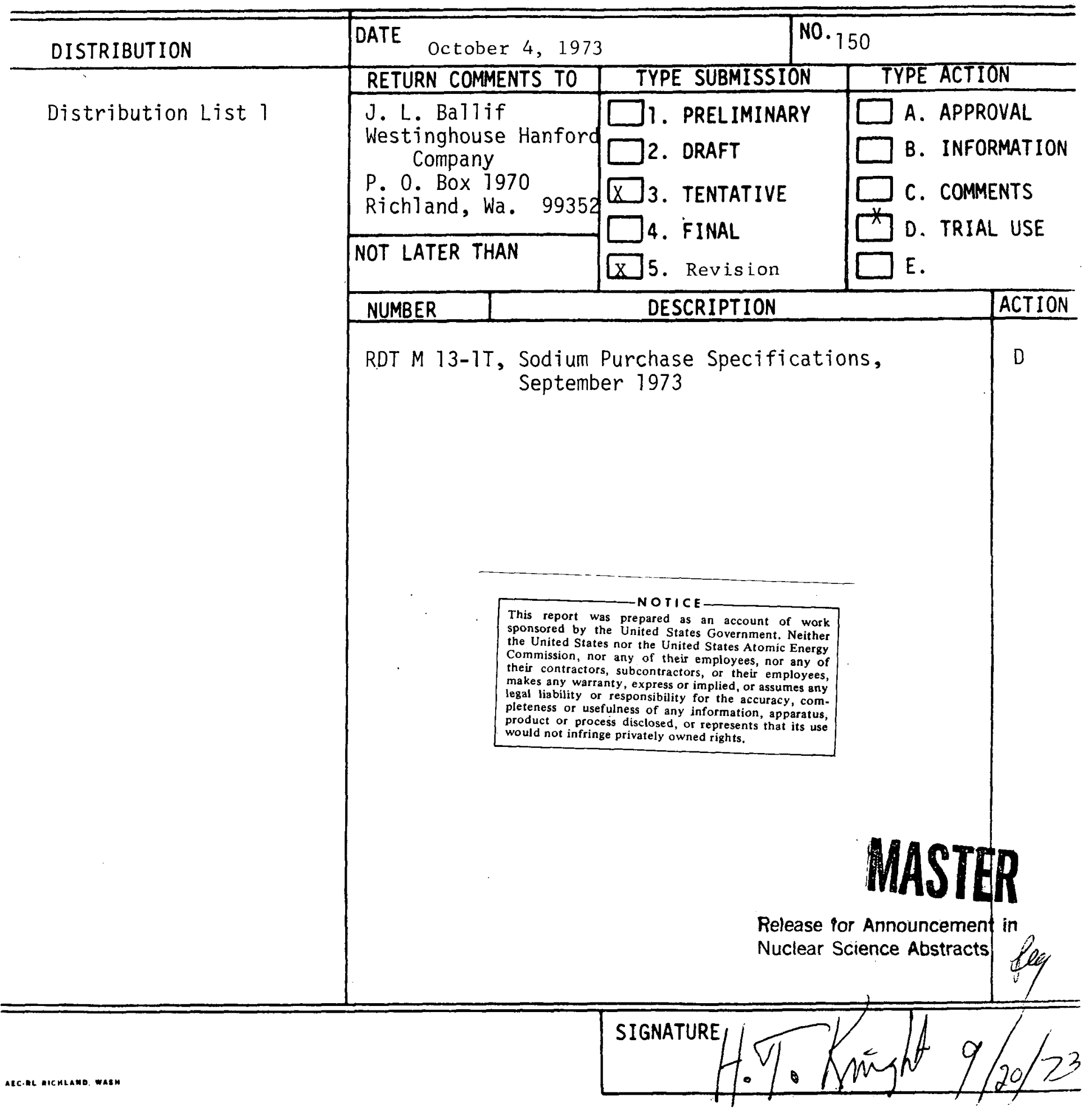




\section{DISCLAIMER}

This report was prepared as an account of work sponsored by an agency of the United States Government. Neither the United States Government nor any agency Thereof, nor any of their employees, makes any warranty, express or implied, or assumes any legal liability or responsibility for the accuracy, completeness, or usefulness of any information, apparatus, product, or process disclosed, or represents that its use would not infringe privately owned rights. Reference herein to any specific commercial product, process, or service by trade name, trademark, manufacturer, or otherwise does not necessarily constitute or imply its endorsement, recommendation, or favoring by the United States Government or any agency thereof. The views and opinions of authors expressed herein do not necessarily state or reflect those of the United States Government or any agency thereof. 


\section{DISCLAIMER}

Portions of this document may be illegible in electronic image products. Images are produced from the best available original document. 


\section{R I T M 13-1T}

Supersedes

RDT M 13-1T, April 1973
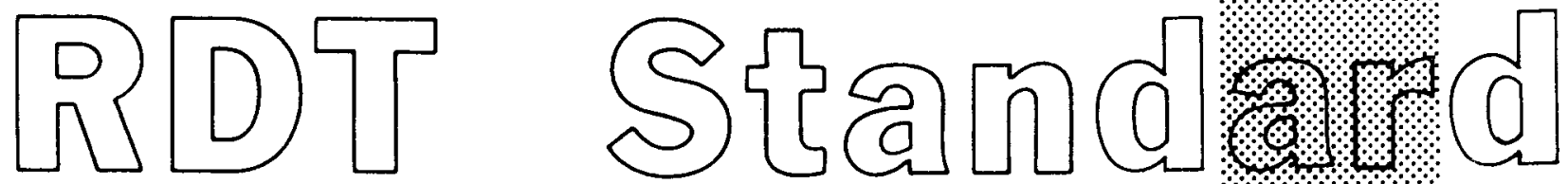

SODIUM PURCHASE SPECIFICATIONS

\section{SEPTEMBER 1973}

Any further distribution by any holder of this document or of the data therein to third parties representing foreign interests, foreign governments, foreign companies, and foreign subsidiaries or foreign divisions of U.S. companies should be coordinated with the Director, Division of Reactor Research and Development, U.S. Atomic Energy Commission.

Division of Reactor Research and Development United States Atomic Energy Commission 


\section{TABLE OF CONTENTS}

\section{$\underline{\text { Page }}$}

1. SCOPE

1.1 General

1.2 Definitions

2. APPLICABLE DOCUMENTS

2.1 RDT Standards

2.2 Government Standards and Specifications

2.3 Other Applicable Standards and Drawings

3. REQUIREMENTS

3.1 Purity Requirements

3.2 Removal of Particulate Matter

3.3 Component Cleanliness

4. QUALITY ASSURANCE REQUIREMENTS

4.1 Sampling and Analysis

4.2 Shipping Containers

4.3 Cover Gas

4.4 Container Identification

4.5 Quality Verification Program

5. ORDERING DATA AND NOTES

5.1 Ordering Data

5.2 Notes 
RDT STANDARD

UNITED STATES ATOMIC ENERGY COMMISSION DIVISION OF REACTOR RESEARCH AND DEVELOPMENT
RDT M 13-1T

DATE September 1973

PAGE OF 5

\section{SCOPE}

1.1 General. This standard establishes purity, quality assurance, and delivery requirements for the procurement of bulk sodium intended for use in sodium cooled fast breeder reactors and for use in nonreactor test and experimental systems in the Fast Breeder Reactor (FBR) program.

\subsection{Definitions.}

1.2.1 Batch. The term "batch" as used in this standard shall be understood to mean the quantity of sodium in drums filled by the supplier from a single, unaltered sodium source for a specific purchaser order.

1.2.2 Class I Systems. All sodium systems associated with fast breeder reactors. This includes the primary and secondary systems and other associated loop systems. systems.

\subsubsection{Class II Systems. Nonreactor test and experimental sodium}

1.2.4 Filter. An in-line device containing a metal screen or frit to retain particulate material that may be present in sodium. Acceptable screen and frit materials are Type 304 and Type 316 stainless steels.

1.2.5 Lot. The term "lot" as used in this standard shall be understood to mean the quantity of sodium contained in a filled tank car.

\section{APPLICABLE DOCUMENTS}

The following documents are a part of this standard to the extent specified herein. The issue of a document in effect on the date of invitation to bid, including any amendments also in effect on that date, shall apply unless otherwise specified. Where this standard appears to conflict with the requirements of a referenced document, such conflict shall be brought to the attention of the purchaser for resolution.

\subsection{RDT Standards.}

RDT F 2-4T Quality Verification Program Requirements

RDT F 3-40T Methods for the Analysis of Sodium and Cover Gas

2.2 Government Standards and Specifications.

Code of Federal Regulations, Title 49, Transportation 
2.3 Other Applicable Standards and Drawings. Other standards and drawings as needed may be cited in the Ordering Data.

\section{REQUIREMENTS}

\subsection{Purity Requirements.}

3.1.1 Sodium intended for use in Class I systems shall meet the following purity requirements:

1. Overall purity $(\mathrm{Na}+\mathrm{K})$ of $\geq 99.90$ percent.

2. Requirements of Table 1 .

Table 1-Maximum Impurity Limits

\begin{tabular}{|c|c|}
\hline Element & Limit (ppm) Maximum \\
\hline B & 25 \\
\hline $\mathrm{Ca}$ & 10 \\
\hline $\mathrm{C}$ & 30 \\
\hline $\mathrm{C} 1$ & 30 \\
\hline Li & 5 \\
\hline $\mathrm{K}$ & 1000 \\
\hline S & 10 \\
\hline $\mathrm{U}$ & 0.01 \\
\hline
\end{tabular}

3.1.2 Sodium intended for use in Class II systems shall meet the following requirements:

1. Overall purity $(\mathrm{Na}+\mathrm{K})$ of $\geq 99.90$ percent.

2. Contain no more than $10 \mathrm{ppm}$ calcium, and no more than $1000 \mathrm{ppm}$ potassium.

3.1.3 The quantity of sodium to be purchased, and whether the purity requirements for Class I or Class II systems are applicable, will be specified in the Ordering Data.

3.2 Removal of Particulate Matter. The sodium shall be filtered, at a temperature not greater than $300^{\circ} \mathrm{F}$, through a filter of 20 micron porosity -- a filter that will remove at least 98 percent of particles larger than 7 microns and 100 percent of particles larger than 25 microns. The filter shall be installed in the main transfer line upstream from the inlet to the sampling system, and the filtering operation shall be carried out at the time the sodium is being sampled and while the sodium is being loaded into either tank cars or drums. 
3.3 Component Cleanliness. All internal surfaces of transfer lines and shipping containers shall be cleaned and inspected as stipulated below prior to the loading of each lot.

3.3.1 Tank cars used to transport Class I and Class II sodium shall meet the following acceptance criteria.

3.3.1.1 The interior smooth surfaces (rust excluded, see 3.3.1.5) of the tank car shall be clean to the extent that no contamination of any surface is visible, without magnification, to a person with normal visual acuity, natural or corrected. In addition, all smooth surfaces shall be clean to the extent that wiping with a clean lint-free unbleached cloth either dry or moistened (but not saturated) with technical grade alcohol shall produce no change in the appearance of the wiped surface.

3.3.1.2 Gouges produced by cleaning tools are permissible provided that they contain no scale or powder (excluding rust) visible to the naked eye. If rust appears it shall be no more than a thin film.

3.3.1.3 Flanges and valves shall be free of loose rust and residue. Prior to reassembly of the tank car dome, all flanges shall be free of oil and grease.

3.3.1.4 Prior to insertion, the dip tube assembly shall be free of oil and grease (both outside and inside) as determined by lack of discoloration on a clean cloth. In addition, a clean cloth which offers reasonable resistance against the inside walls of the dip tube, pulled through the dip tube, shall not dislodge any scaly material.

3.3.1.5 Thin films of rust are acceptable provided that no more than one percent of the total inside surface area of the tank car is covered. Thin films of rust are defined as superficially corroded areas of red, brown or black discoloration. The rust observed may be either localized or general; that is, the rust may be present in spots or streaks or as a continuous film. Where localized rusting is involved, the total included area (the rusted area plus the included unrusted area) shall be used to determine the percentage involved rather than the actual area observed.

3.3.2 Only new drums shall be used for shipping sodium. These drums shall be inspected by lowering a bung light into the drum. The drum shall be free of all residue and shall contain no more than a thin film of rust.

3.3.3 The permanent piping used for transferring the sodium from the bulk supply to the shipping containers shall be flushed with five or more line volumes of sodium from the bulk supply; where "line volume" shall be construed as the internal volume of all piping of the delivery system which could become contaminated with sodium that may not meet the purity specifications for Class I or Class II systems.

3.3.4 Removable connecting pieces used in the delivery system shall be cleaned to the extent that the interior surfaces meet the cleanliness criteria of $3.3 .1 .1,3.3 .1 .4$ and 3.3 .1 .5 . 
3.3.5 The supplier sha11 furnish a detailed cleaning plan and procedure for the purchaser's approval prior to filling any containers with sodium i...ess otherwise specified in the ordering Data. No filling of sodium containers shall be started until all requirements have been approved by the purchaser. The purchaser shall be given the option of having an observer present during the cleaning, sampling, and container loading steps.

\section{QUALITY ASSURANCE REQUIREMENTS}

\subsection{Sampling and Analysis.}

4.1.1 Sampling requirements for sodium intended for use in Class I and Class II systems are as follows.

4.1.1.1 The supplier shall sample the sodium as each tank car is being filled. The supplier shall submit for purchaser approval sampling and analysis procedures that will be used to certify the purity requirements. Laboratory methods for purity measurements shall be in accordance with the requirements of applicable sections of RDT F $3-40$ as specified in the Order....ig Data of the purchase specification. Each sample shall be tagged to show the date, purchase order number, batch or lot number, and sample sequence.

4.1.1.2 The supplier shall furnish the purchaser with a document certifying that the purity of each lot or batch meets the requirements of 3.1 .1 or 3.1 .2 as appropriate. By supplying the certificate of purity, the supplier shall be authorized to ship any certified lot or batch of sodium, but he may delay shipment until the lot or batch has been accepted by the purchaser. in the Ordering Data.

4.1.1.3 Additional sample requirements shall be as specified

\subsection{Shipping Containers.}

4.2.1 All sodium shipments shall comply with Department of Transportation (DOT) regulations, 49 CFR 170 to 179.

4.2.2 The purchaser shall indicate, in the Ordering Data, the type of containers required, i.e., drums or tank cars.

4.2.3 The purchaser has the option of inspecting or testing any shipping container, or the cover gas thereon upon delivery at the purchaser's site to insure that the integrity of the containers was not violated during transit. In any case where the integrity of the containers has been violated, the supplier shall be notified and shall provide procedures for corrective action for purchaser approval.

4.3 Cover Gas. The inert cover gas to be used over the sodium during the filling operations and during shipping will be specified in the ordering Data by the purchaser. The cover gas shall be argon, helium, or nitrogen of purity $\geq 99.995$ percent and shall have a dew point of $-70^{\circ} \mathrm{F}$ or lower. 
4.4 Container Identification. Each container shall be labeled "Metallic Reactor Grade Sodium--Class I" or "Metallic Reactor Grade Sodium--C1ass II". Each container shall also be labeled with the following identification: lot or batch number, date of filling, customer's purchase order number, gross weight, tare, net weight, and type of inert cover gas over the sodium.

4.5 Quality Verification Program. The supplier shall prepare and carry out, in accordance with RDT F 2-4, a quality verification program covering the following:

1. Removal of particulate matter.

2. Container cleanliness.

3. Sampling, and preservation of sample identity and integrity.

4. Cover gas quality.

5. Other items specified in the Ordering Data and Notes.

5. ORDERING DATA AND NOTES

5.1 Ordering Data. The purchaser shall furnish the supplier with the following information:

1. Title and number of this standard and all other applicable standards $(2.0)$.

2. Name of purchaser.

3. Delivery site.

4. Quality of sodium and whether the purity requirements for Class I or Class II systems are applicable (3.1.3).

5. Cleaning plan requirements (3.3.5).

6. Type of shipping container (4.2.2).

7. Method of shipment.

8. Required delivery date at specified site.

9. Type of cover gas (4.3).

10. Items for quality verification program (4.5).

5.2 Notes. Any special requirements that are deemed necessary by the purchaser and that are concerned with the inspection, testing, and delivery of the sodium and with containers, and samples shall be specified. 